\title{
THE IMPACT OF ECONOMIC CRISIS UPON ROMANIAN AGRO-FOOD SYSTEM: CHALLENGES AND POSSIBLE SOLUTION
}

\author{
IGNAT, R[aluca]
}

\begin{abstract}
The added value of Romanian agricultural production decreased between 2008 and 2009 by $24.1 \%$, while the EU's decreased by $12.3 \%$. With an utilized agricultural area in 2008 of 0,411 ha per capita, about twice the European average which is 0,212 ha, Romania gets agricultural production far below the EU-27. There may be at least six agricultural development model. There is no future for clasical solutions for Romanian agriculture, considering years to be recovered. There is a creative approach to constitute crossborder associations of farmers that will boost economic performance in the sector will conduct to regional economic growth.
\end{abstract}

Key words: agriculture, agricultural development model, producers associations, rural development, crisis

\section{INTRODUCTION}

Questions about agriculture and rural development's importance are not few. The issues consist in determining their role in strategic development. The agricultural development history may be divided into three periods: between 1950 and 1960, when economics defined agricultural development by increasing output/capita; in the $70 \mathrm{~s}$, when economists from developed countries replaced these theories with empirical studies on rural areas and used, for the first time, for this fields, income, distribution, employees; the $80 \mathrm{~s}$ and $90 \mathrm{~s}$ that brought another approach: the agricultural development to be based on food security and sustainability (Staatz, J. M., Eicher, C. K., 1998: pp. 8). Nowadays we discuss about sustainable development, competitiveness and a convergent policy towards these goals. Both national and European public policies aim these objectives. And both agriculture and rural development are reshaped from another perspective: the possible solutions for obtaining higher economic results.

Models for agricultural development become much more important. Literature review offers at least six models for agricultural development: frontier model, conservation model, urban-industrial impact model, diffusion model, high-payoff input model, induced innovation model (Ruttan, W. V, 1998: pp. 155). Following, the research question normally comes: what would be the best solution for Romanian agriculture? EU intervenes to support agriculture in different ways, but the solutions are not identical for each country. Each acts in a justified manner in order to preserve traditions and individual and group competitiveness of domestic farmers. Actions are, yet, under the CAP.

The study is based on documentation on the existing models of development of agriculture and rural areas. A solution for Romanian agriculture and rural development has been proposed.

\section{ROMANIAN AGRICULTURE POST CRISIS}

A pertinent analysis of agro-food sector in the pre and post crisis is necessary. On the one hand, the economic context is one of these elements. In Romania in 2010, GDP/capita was 5700 Euro, comparing to 24500 Euro, the average of EU-27 (Eurostat, Basic figures on the EU, 2011, pp. 3). The unemployment rate in the EU-27 was $9.6 \%$ in the last half of 2010 , versus $7.4 \%$ in Romania the same period (Eurostat, Basic figures on the EU, 2011, pp. 5).

The added value of agricultural production decreased between 2008 and 2009 by $24.1 \%$, while the EU's decreased by $12.3 \%$. But, it seems that we are used to have this situation. We are hiding behind unnecessary excuses like there is a difference of years to recover between Romania and other EU countries, although not many solutions were tried during the previous years. And yet: in year 2010, real agricultural output in Europe grew $9.9 \%$, compared with the mitigation of the previous years.

On the other hand, agro-food system has features that distinguish it from the rest of total sectors: depends to a large extent by environmental and weather conditions. With an utilized agricultural area in 2008 of 0,411 ha per capita, about twice the European average which is 0,212 ha, Romania gets agricultural production far below the EU-27.

Thus, agricultural price index between 2008 and 2011 has increased considerably. This is inevitably painful for the actors on the products' chain. The effect is propagated. Scissors prices acted since 1929 is too high in our country's agriculture, and has a bad huge impact on this sector and causes large imbalances. Moreover, total investment fell by $2,9 \%$ between first semester of 2010 and first semester of 2011, and the investments in agriculture represents only $5,4 \%$ of the total. It is very little compared to the needs of this sector. This is another crisis effect upon agriculture. More or less direct effects were propagated in the chain: the SMEs decreasing number; the jobs' supply in this sector is reducing; the fertilizer, chemical fertilizers, pesticides' costs are rising, the loans for agriculture, even loans in progress, are increasing their costs; the production costs are increasing, conducting to an obviously spread effect.

In addition, food industry, most often, was unable to absorb agricultural production, especially in the fruit and vegetables sector. The absence of insurances in the system should be added, because of difficult conditions imposed by the financial actors, and lack of financial power of agricultural producers and processors.

\section{ROMANIAN AGRICULTURE'S CHALLENGES}

We could even say that public policies have been CAP reactive and not anticipatory. The Romanian agriculture, as well as, Romanian rurality faces several challenges:

a) lack of a clear, easy to follow policy, with annual plans and specific purpose for the farmer, even if the strategy exists, meaning National Programme for Rural Development.

b) unbalanced access in time and space of pre-accession and to the structural funds causes of social and economic differences, and in addition, excessive bureaucracy to access EU funds.

For example, the number of approved and financed projects broken down by regions on Measure 322 "Village renewal and development, improving basic services for rural economy and population and enhancement of rural heritage" of the National Rural Development Programme of Romania, is very different on regions, taking into considerations both their number and 
value, leading to differentiation of regions according to these concerned objectives.

c) existence of a vicious circle in which the Romanian farmer is situated (Figure 1) which does not allow him to perform or to become competitive. The challenge is to find niches where it may intervene.

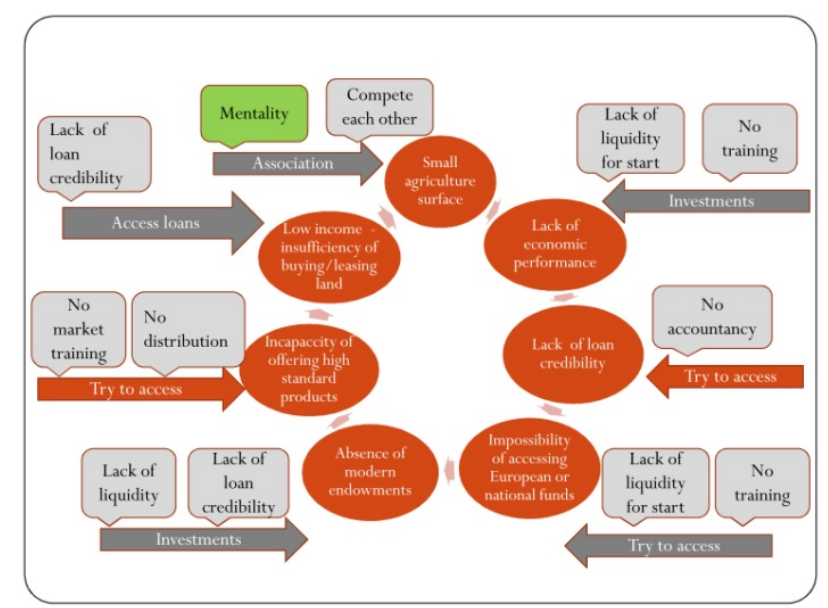

Fig. 1 Vicious circle of the Romanian farmer

d) the existence of unprofitable mentality of farmers.

Perhaps the most sensitive problem of the Romanian agriculture is the small agricultural area of individual farms 3,5 ha, compared to 12,6 ha as the EU-27 average. Farmers have displayed reticence to associative solutions, given recent, communist period history.

e) the existence of poor road, rail, public service, water and sanitation, communications infrastructure

\section{A POSSIBLE SOLUTION: CROSS-BORDER ASSOCIATIONS OF FARMERS}

Establishing some forms of cross-border cooperation to provide farmers the services that they need, and also, to meet other economic needs that they feel has some innovative aspects than the other projects of this kind. Cross-border associations of farmers should be established within the EU, at Romania's borders with Hungary or Bulgaria. In those areas European interests are identical, the legal framework is harmonized and the countries may access structural funds for common purposes.

Cross-border cooperation involves joint efforts and meetings between farmers of different nationalities in order for them to reach certaing purposes: use of techniques, purchase with raw materials, marketing and trade, labour etc. Associations stimulate culture, traditions, and economic and social cross-border exchanges. The impact upon the region could also be given by the intensification of trade relations that will propagate in all fields:

- social - through business relations and friendship which the farmers will develop;

- economic - development of related activities: transport, tourism, consulting and other types of services;

- financially - using banking services to organize and conduct business;

- tax - through local taxes that local authorities will collect from cross-border associations;

- cultural - through participation at common socio-cultural events: fairs, exhibitions etc.

Investors in agriculture are likely to find developing solutions in cross-border partnerships for the provision with raw materials and the access of new markets.

Starting from these premises, it is important to develop institutionalized forms of cooperation to boost the cross-border economic relations and, ultimately, to increase regional economic performance of agriculture.
The overall objective of setting up these associations is to foster cross-border cooperation and increase the economic performance of regional agriculture, and, to increase the income for local authoritie.

Also, the cross-border associations aim:

- to stimulate the exchange of technical knowledge among farmers on agricultural production;

- to encourage the know-how transfer for crop, husbandry, marketing, farm management etc.;

- to boost cooperation relations between members of the association at any level.

This model may be replicated on as many as possible crossborder regions. And it may address to several needs of the farmers.

The limitations of the model are given by the aversions against associative forms in agriculture of the Romanian farmers due to psychological and historical reasons. But the innovative character of this model consists in the cross-border approach, and this may be its challenging advantage in order to transform the Romanian farmer into its followers.

\section{CONCLUSION}

The challenges facing Romanian agriculture are neither few nor small. They come from a historical perspective and still propagate.

Not only global economic crisis has had effects on the results of our country agriculture, but agriculture itself, couldn't give the expected results. Putting pressures on the sector by saying that it is the Romanian economic great expectation is unjustified. In addition, efforts made to support the sector's financing are minimized by the farmers' inability, more or less, to make payments, for the beneficiaries. They are in a vicious circle, and they hardly may find solutions to break it.

Integrated efforts are needed in order to offer the chance of knowledge transfer. The high-payoff model which cross-border associations in agriculture are based on could bring added value for the agriculture's performance.

The presented solution tries to answer to these problems and to adapt to international agricultural development models.

\section{ACKNOWLEDGEMENTS}

This work was cofinanced from the European Social Fund through Sectorial Operational Programme Human Resources Development 2007-2013, project number POSDRU89/1.5/S/59184 „Performance and excellence in postdoctoral research in Romanian economics science domain”.

\section{REFERENCES}

de Noronha Vaz, T., J. Morgan, E., Nijkamp, P.(2006) „The New European Rurality Strategies for Small Firms", Ashgate Publishing Limited, England, ISBN 075464536 3 ;

Istudor, N, Bogdanova, M., Manole, V., Ignat, R., Petrescu, I.E., (2010) „Education and training needs in the field of agriculture and rural development in the Lower Danube Region”, Amfiteatru Economic Journal, special number no. 4/2010, Bucharest, ASE Publishing House, ISSN 1582 9146;

Ruttan, W. V - „Models of Agricultural Development”, International agricultural development, Third edition, The Johns Hopkins University Press, London, 1998, ISBN 080185878X, 0801858798 (pbk.);

Staatz, J. M., Eicher, C. K. - „Agricultural development ideas in historical perspective", International agricultural development, Third edition, The Johns Hopkins University Press, London, 1998, ISBN 080185878X 0801858798 (pbk.),

Eurostat, Basic figures on the EU, 2011; 